\title{
Gaul Ala Rasul: Interpretasi di Masyarakat
}

\author{
Dinil Abrar Sulthani \\ Universitas Islam Jakarta \\ Email: dinil.leader@gmail.com \\ Received: June 27, 2020 | Accepted: December 6, 2020
}

\begin{abstract}
This article was written to explain slang for the younger generation connected with the example of the Prophet. In the perception of some people, slang has a bad connotation. This is because some of the younger generations carry out activities that are contrary to local religious and legal values. The conditions of the times have an influence on the development of the personality of the younger generation, including in their attitude and actions to be superior. This thought paper aims to discuss the activities of the younger generation, such as challenges, problems, and their potential. The writing of thoughts is described using the literature study method with a qualitative descriptive analysis approach. The results of the study show that 1) The younger generation can maximize their potential by interacting like the Prophet's example, 2) Interacting politely with their friends, and 3) The younger generation can be role models for the community. The conclusion is that the younger generation get along in the best way. In imitating the Prophet, the younger generation needs to do: 1) Starting from themselves to worship and preach, 2) Reminding and motivating each other, and 3) Doing activities as a form of love for Allah.
\end{abstract}

\begin{abstract}
Abstrak
Tulisan ini dibuat untuk menjelaskan tentang gaul bagi generasi muda dikaitkan dengan teladan Rasul. Dalam persepsi sebagian masyarakat, gaul berkonotasi kurang baik. Perihal tersebut karena sebagian generasi muda melakukan aktivitas yang berseberangan dengan nilai agama dan hukum setempat. Kondisi zaman memberi pengaruh pada perkembangan kepribadian generasi muda, termasuk dalam bersikap dan berbuat menjadi pribadi unggul. Tulisan pemikiran ini bertujuan untuk membahas aktivitas generasi muda, seperti tantangan, masalah, dan potensi yang dimilikinya. Tulisan pemikiran dijabarkan menggunakan metode studi pustaka dengan pendekatan kualitatif analisis deskripsi. Hasil dari kajian menunjukkan bahwa (1) generasi muda bisa memaksimalkan potensinya dengan cara berinteraksi seperti yang teladan Rasul; 2) berinteraksi dengan sopan bersama teman-temannya; dan 3) generasi muda bisa menjadi teladan bagi di lingkungan masyarakat. Kesimpulan tulisan bahwa generasi muda bisa bergaul dengan cara yang terbaik. Dalam meneladani Rasul, generasi muda perlu melakukan;1)Mulai dari dir sendiri untuk beribadah dan berdakwah, 2)Saling mengingatkan dan memotivasi sesama teman, dan 3)Melakukan aktivitas sebagai wujud rasa cinta kepada Allah.
\end{abstract}

\section{Keywords}

Slang, young generation, prophet, society 


\section{Pendahuluan}

Gaul yang sering dipahami sebagain masyarakat lebih ke arah suka kumpul dan kadang cenderung dengan persepsi negatif. Pada dasarnya persepsi itu dianggap wajar oleh sebagian masyarakat karena ada faktanya, seperti generasi muda cenderung salah gaul dalam berteman. Ini ditandai dengan adanya kasus, seperti merokok dianggap wajar, tawuran, suka dandan berlebihan, candu bermain games, berpacaran dan sebagainya.

Adanya contoh kasus tersebut merupakan daftar sikap gaul yang perlu dihindari oleh setiap orang. Karena, dengan salah dalam bergaul akan berujung pada keburukan. Ajaran Islam memberikan pesan bahwa kebaikan yang diperbuat seseorang akan untuk dirinya sendiri, dan keburukan yang diperbuat seseorang juga akan kembali pada dirinya sendiri. Untuk itu, perlu bagi setiap manusia memahami dengan benar perihal apa saja yang harus dilakukan dengan baik dalam menjalani kehidupan, dan perihal apa saja yang harus dihindari agar kita terjauh dari lembah kesengsaraan. Perihal tersebut dapat dilihat dalam Qs. Ar-Rahman ayat 60: "Tidak ada balasan kebaikan kecuali kebaikan (pula)"

Di sisi lain, ada juga sebagian pemahaman masyarakat menganggap gaul itu perihal penting. Secara khusus jika gaul itu dapat mendatangkan pertemanan yang baik dan manfaat yang banyak. Gaul inilah yang disebut sebagai perilaku positif. Perilaku positif yang lahir dari hati yang bersih dan jiwa yang tenang, sehingga tampilan yang ada pada diri setiap manusia akan terpancar aura kebaikan. Perilaku yang baik tersebut dapat menjadi uswah atau teladan bagi teman-temannya. Perilaku adalah tindakan nyata dari memiliki pikiran dan perasaan positif (Mardiyansyah \& Senda, 2011). Hal ini penting untuk diusahakan, karena pada zaman sekarang ini sudah mulai sulit ditemukan orang layak diteladani, khususnya dalam pergaulan generasi muda.

Oleh karena itu, pemilihan sikap menjadi baik atau buruk semua terpulang pada diri setiap individu. Itulah yang menjadi identitas setiap manusia, yang dikenal sebagai pilihan sikap gaul. Jika setiap manusia memahami pentingnya bergaul dengan baik, maka ia terlebih dahulu memperbaiki dirinya menjadi baik. Memperbaiki diri seperti menjaga ucapan jangan sampai menyakiti dan menzalimi yang lain, dan menjaga tangan atau kelakuan dengan menghindari kejahilan dan membuat kegaduhan, serta menjaga hati untuk tetap benar dam jujur. Sebab, hati yang bersih akan memancarkan kebaikan, begitu pula sebaliknya, jika hati kotor maka akan terlihat buruknya.

Sehingga, jelaslah bahwa gaul itu memiliki syarat yang harus dipenuhi yaitu dengan selalu berusaha meningkatkan kualitas dan kuantitas kebaikan. Kebaikan itu mudah dan sederhana, serta bisa dilakukan kapan saja (Saputra, 2018). Dengan kata lain, generasi muda hendaknya selalu berusaha meningkat kebaikan, dengan prinsip; hari ini harus lebih baik dari hari kemarin, lusa harus lebih baik dari hari ini. Perihal ini menandakan gaul yang positif itu harus diupayakan, bukan otomatis langsung melekat pada diri. Sebab banyak tantangan ; seperti nafsu, rayuan setan, dan mementingkan diri sendiri.

Tulisan pemikiran ini akan menguraikan secara lengkap dan jelas sikap bergaul pada generasi muda. Mengingat perkembangan zaman yang terus berkembang, tentu akan membawa berbagai tantangan dan juga peluang. Generasi muda perlu bersikap dan berakhlak baik untuk menjaga eksistensi dan tatanan hidup di masyarakat. Upaya yang dapat dilakukan dengan cara memperkuat kepribadian akhlak sesuai nasihat Rasul. Sikap akhlak Rasul menjadi panduan bagi generasi muda untuk bergaul atau berinteraksi dengan teman-temannya. 
Teladan Rasul sudah tertuang dalam konsep ajaran agama Islam. Untuk itu, tulisan kajian literatur ini mampu memperkuat dan mengukuhkan substansi ajaran Islam. Bahasan gaul menjadi menarik karena selama ini bahasan tersebut dianggap memiliki konotasi yang cenderung ke arah tidak baik. Padahal jika ditelusuri lebih dalam, penggunaan bahasa gaul ini sebenarnya bisa menjadi media bagi konsep ajaran agama Islam masuk ke dalam persepsi pemikiran generasi muda.

Perihal tersebut perlu untuk menjadi perhatian, karena generasi muda zaman sekarang adalah harapan bagi semua pihak; harapan orang tuanya, bangsanya dan juga agama. Eksistensi keberadaan agama, khususnya agama Islam tergantung pada generasi muda. Jika ia dibekali pemahaman agama yang baik, maka dalam beraktivitas sesuai ajaran agama dalam kehidupan sehari-hari. Pemahaman agama itu akan menguat pada generasi muda, sehingga mereka dapat menjaga dan melestarikan pemahaman agama pada generasi-generasi selanjutnya. Untuk itu, generasi muda hendaklah berusaha mengubah dunia, bukan hanya dengan kata (refleksi) tetapi juga dengan aksi dengan landasan pemikiran-pemikiran reflektif yang cerdas dan mencerahkan (Rochmi, 2012).

Tulisan kajian pikiran ini memakai pendekatan kualitatif dengan analisis deskripsi. Analisis yang dikembangkan berdasarkan kajian literatur yang relevan dan fenomena yang berkembang. Dengan harapan hasil kajian pemikiran ini dapat memberikan masukan dan saran bagi praktisi, pembaca, generasi muda, dan peneliti selanjutnya untuk terus mempertahankan dan mengikuti teladan Rasul. Karena, zaman selalu membawa perubahan situasi dan kondisi. Maka dengan adanya teladan Rasul, umat manusia, khususnya generasi muda tetap bisa menjaga eksistensinya sebagai manusia mulia di masyarakat.

\section{Metode}

Kajian ini menggunakan metode pemikiran reflektif. Metode kajian pemikiran reflektif adalah kajian aktif yang dilakukan secara gigih dan terus menerus, serta mempertimbangkan dengan seksama segala sesuatu yang dipercaya kebenarannya. Metode pemikiran reflektif menjadikan perasaan, penghayatan, dan insight sebagai sumber kajian penting untuk mencapai taraf penyimpulan. Metode kajian ini dimulai dari merasakan fakta-fakta empiris (something happened), kemudian menghayati perasaan (what happened in me), mengeksplorasi insight dari kejadian yang dialami (so what), untuk kemudian melakukan sistematisasi menuju penyimpulan akhir.

\section{Hasil Kajian dan Pembahasan Makna Gaul Ala Rasul}

Gaul dapat juga diartikan sebagai perilaku yang diterapkan seseorang dalam berinteraksi dengan orang lain. Gaul juga identik dengan adanya usaha diri untuk menyalurkan bakat dan hobi dalam aktivitas sehari-hari. Usaha penyaluran bakat ini ditandai dengan keikutsertaan dalam aktivitas pengembangan diri, baik di sekolah maupun bersama dengan teman-temannya. Seseorang yang memiliki hobi akan berusaha keras menempuh hal yang diinginkannya.

Gaul dapat terlihat dari gaya dan gestur tubuh dalam menyampaikan pesan komunikasi. Manusia dalam menyampaikan pesan komunikasi berkaitan erat dengan gerakan tubuh dan sebagainya. Dengan kata lain, melihat gaya dan gestur tubuh juga memberikan gambaran kepada kita bahwa setiap manusia mempunyai sikap yang harus dilihat secara cermat, baik yang kelihatan secara nyata maupun juga tersirat. 
Untuk memahami kondisi seseorang bukan perkara mudah, perlu membutuhkan berbagai perenungan mendalam. Tidak sedikit orang salah memberikan kesimpulan terhadap orang lain, karena kurang tepat dalam menyimpulkan apa yang dilihatnya. Seperti, ia melihat orang lain buruk padahal sebenarnya ia baik, karena tidak terekspos kebaikannya. Atau sebaliknya, kita cukup terkesan melihat seseorang padahal sebenarnya itu hanya bagian dari pencitraan. Jadi, perlu ada perenungan terlebih dahulu dalam menilai sikap seseorang.

Salah dalam menyimpulkan atau menilai seseorang juga bagian dari salah gaul. Seperti ungkapan, semut di seberang lautan dapat terlihat, namun gajah di depan mata sulit dilihat. Sikap manusia kadang hanya bisa menilai orang lain, tetapi lalai melihat diri sendiri. Boleh jadi kita mencap orang lain salah gaul, padahal sebenarnya kita sendiri yang salah gaul. Dengan demikian, sikap tersebut mempersulit diri sendiri untuk memperbaikinya, sebab orang yang merasa benar cenderung akan mengabaikan nasihat orang lain.

Generasi muda sekarang tentu berbeda dengan generasi pada zaman lalu. Selain berbeda zaman, juga berbeda dalam hal informasi dan teknologi. Sebagai contoh, generasi muda sekarang selalu bersama gawai (hand phone) di tangannya, sedangkan generasi zaman dulu, belum memakai teknologi canggih seperti sekarang. Tentu ini mengindikasikan cara bergaul juga tentu berbeda. Langkah awal yang baik ialah mengintegrasikan kedua zaman tersebut. Zaman sekarang diperlukan ketangguhan dalam menghadapi perubahan zaman, disertai dengan keterampilan mumpuni sesuai dengan kebutuhan dan tuntutan global (Ananta, 2018). Oleh karena itu, orang tua yang memiliki masa muda yang berbeda dengan anaknya harus paham akan kondisi sekarang.

Orang tua kurang tepat jika harus memaksakan kehendaknya kepada anak-anak yang hidup di masa sekarang. Bahkan pada usia dini, keteladanan orang tua sangat berpengaruh terhadap kepribadian anak. Segala yang dilakukan oleh orang tua dianggapnya selalu benar dan paling baik (Baharits, 1996). Di samping itu, pendidik juga tidak boleh menyamakan cara mengajarnya seperti yang telah diterimanya dahulu dari gurunya. Dahulu mungkin dianggap wajar, guru memberikan hukuman kepada siswa dengan pukulan ringan. Namun, zaman sekarang tindakan tersebut akan menimbulkan kegaduhan di dunia pendidikan. Dengan kata lain, tidak boleh ada nostalgia dengan unsur paksaan, sebab paksaan bukanlah nilai yang mudah diterima oleh manusia.

Generasi muda yang hidup di zaman sekarang janganlah memilih sikap gaul yang negatif, seperti merasa bangga dan superior hidup di zaman serba canggih. Perihal ini akan mendatangkan kesombongan yang menghantarkan pada keburukan. Generasi muda tidak boleh merasa puas, sebab 5 atau 10 tahun ke depan perubahan zaman juga akan berbeda. Hal ini dikarenakan informasi dan teknologi berkembang pesat. Manusia selalu berupaya keras dalam melakukan penemuan-penemuan yang dapat dikembangkan dan dipakai oleh seluruh masyarakat. Ini menjadi pertanda bahwa generasi muda juga harus membekali diri dengan pengetahuan yang cukup.

Oleh karena itu, generasi muda hendaknya memiliki kepribadian dan bergaul dengan baik. Kepribadian adalah kualitas seseorang yang menyebabkan ia disenangi atau tidak disenangi oleh orang lain (Sunaryo, 2004). Dengan kata lain, bergaul berkaitan dengan kepribadian yang unggul. Waktu berjalan terus tanpa ada toleransi berhenti walaupun sedetik. Detik ke menit, menit ke jam, perubahan waktu demi hari menjadi pertanda bahwa sikap gaul yang harus dilakukan adalah berupaya menjadi baik. Jika salah dalam mengambil prinsip akan salah pula 
dalam menjalani kehidupan. Generasi muda jangan terlena dengan kehidupan yang serba canggih. Untuk itu generasi muda seharusnya mengisi waktu dengan kegiatan positif.

Ala dapat diartikan sebagai meniru, meneladani dari yang lain. Kata ala ini merupakan sebagai penghubung tentang suatu hal. Gaul juga dapat bermakna upaya seseorang dalam mengamalkan dan menirukan yang dilihatnya pada orang lain lalu menerapkannya pada dirinya sendiri. Meniru dengan sekuat tenaga, pikiran dan hati agar mampu menyamakan atau paling tidak mengikuti dari belakang atas orang yang diikutinya. Tentu ini bersifat sangat mungkin, selama ia memahami dan serius dalam mengikutinya dengan maksimal.

Dalam hal meniru ada beberapa hal yang penting untuk diperhatikan, yaitu, Pertama, Pastikan paham dengan hal yang akan ditiru. Artinya, generasi muda harus menentukan terlebih dahulu siapa dan mengapa ingin mengikutinya. Harus ada landasan yang kuat jika ingin meniru sesuatu hal, karena hal tersebut akan menjadi motivasi untuk tetap semangat dalam meniru. Motivasi adalah potensi fitrah yang terpendam, yang mendorong manusia untuk melakukan sesuatu yang mendatangkan kesenangan kepada dirinya atau memuaskan kebutuhan primernya, atau menolak bahaya yang membawa kesakitan dan kesedihan kepadanya (Az-Za'balawi, 2007). Tentu, jika seseorang tidak paham dengan apa yang ditirunya, maka sudah menjadi keniscayaan orang tersebut akan setengah-setengah dalam meniru. Faktor lain bisa muncul, seperti karena unsur terpaksa, atau karena tidak ada kegiatan lain maka meniru adalah opsi terakhir untuk dilakukan. Berbagai argumentasi tersebut sebenarnya kurang baik menjadi dasar dalam meniru.

Kedua, Kumpulkan referensi atau sumber-sumber informasi bagaimana cara meniru yang baik dan benar. Dengan kata lain, gaul tidak cukup dengan paham siapa yang akan ditiru, namun harus paham pula cara mengamalkan agar bisa sama sesuai tiruan. Umat Islam mengenal dan mencintai Nabi Muhammad Saw. Namun, dalam meniru atau meneladaninya ada yang tidak sesuai dengan nasihat dan ajaran Rasul. Tentu ini menjadi ketimpangan, seperti sebuah anekdot; jika ingin menyeberang lautan maka pakailah kapal bukan dengan sepeda. Demikian juga, jika ingin meniru Rasul maka amalkan nasihatnya, bukan malah menambah amalan yang tidak pernah ada teladannya.

Ketiga, Konsisten dalam meniru. Sikap gaul ketiga ini adalah bagian kunci yang harus ditegaskan pada diri untuk selalu siap mengamalkan dimana dan kapan pun, baik di kala senang maupun sedih. Generasi muda harus konsisten dengan apa yang dipilihnya. Sebab setiap pilihan tentu ada konsekuensinya, meniru juga sama. Meniru Rasul harus berusaha keras untuk menjalankan nasihat dan ajarannya dengan baik dan benar sesuai yang ada contohnya. Mengerjakan dengan serius dan kontinyu, karena amalan yang baik itu yang sedikit tetapi dikerjakan secara rutin atau berkelanjutan. Perihal ini menyatakan bahwa saat beramal fokus pada yang kecil dengan rutin, daripada beramal dengan skala besar tetapi hanya sesekali saja.

Tiga langkah di atas dapat menjadi langkah awal jika generasi muda ingin meniru dengan cara yang baik dan benar. Dan cara-cara tersebut saling berintegrasi satu dengan yang lain, karena jika hanya mengamalkan satu cara belumlah lengkap dalam menirukan suatu hal. Kajian meniru ini yang paling penting adalah penentuan profil yang akan ditiru. Generasi muda tidak sedikit yang mengidolakan seseorang yang dianggap publik figur atau entertainment, mereka merasa sedih saat idolanya menderita, idolanya di-bully, ia berusaha membelanya. Padahal idolanya itu tidak pernah memberikan nasihat yang baik dan mengajarkan untuk kebahagiaan di dunia dan akhirat.

Rasul dapat diartikan sebagai utusan, yang membawa syariat bagi umatnya. Rasul yang diutus Allah ke dunia untuk menyampaikan ajaran tauhid guna mengubah perilaku manusia dari 
yang buruk kepada yang baik, dari yang keji dan hina menjadi terpuji dan mulia. Misi dakwah rasul adalah ubudiah kepada Allah, mencintai-Nya dengan segenap jiwa raga, hamba pilihan, makhluk terbaik dan menjadi kekasih Allah Swt serta memiliki umat terbesar sampai akhir zaman, hingga kiamat tiba. Nabi Muhammad adalah pemimpin terbaik dalam menyampaikan ajaran Islam kepada umatnya, dan menjadi rahmat untuk semua makhluk dan alam.

Sebagai Rasul terakhir, Muhammad Saw selalu memberikan keteladanan kepada umatnya dengan sungguh-sungguh, beliau berbuat apa yang dikatakannya dan beliau mengatakan apa yang diperbuatnya. Beliau mengedepankan kejujuran dan kebenaran setiap hela napas dan dalam kondisi apapun. Beliau dikenal sebagai manusia yang bertanggungjawab. Masyarakat semasanya menjuluki beliau sebagai al-amin, orang terpercaya dan berakhlak mulia. Sehingga risalah yang dibawanya dapat diterima umatnya, walaupun usaha tersebut mendapat pertentangan dari berbagai pihak. Dengan izin Allah, risalah Islam menyebar dan diterima masyarakat sampai penjuru pelosok bumi.

Menanamkan tauhid dengan cara yang santun dan jelas, menekankan bahwa pentingnya menyadari arti bertuhan. Yakin kepada Allah dapat memberikan manfaat. Sedangkan, yakin kepada yang lain akan membawa mudarat. Menjadikan risalah sebagai pengobat penyakit hati dan memberikan kabar gembira bahwa jika ingin berbuat baik dan menyucikan diri akan mendapat pahala dan surga. Juga mengisyaratkan bahwa jika generasi muda lalai, maka azab dan murka Allah bisa datang kapan saja. Risalah Islam dipahami oleh semua orang sebagai ajaran murni, walaupun bagi mereka yang masih mengingkari kerasulan Muhammad. Sebab, risalah Islam hadir bukan sebagai ajaran paksaan, tetapi ajaran yang santun memberikan ruang pikir dan dialog.

Poin penting yang menjadi catatan, bahwa manusia patut memperhatikan akhlaknya. Rasul hadir sebagai pengubah keadaan situasi, perilaku, kebiasaan, dan akhlak yang telah berlangsung lama baik di Mekah maupun Madinah. Mengubah akhlak buruk menjadi akhlak baik bukanlah perkara mudah seperti membalikkan telapak tangan. Rasul mendapat pertentangan dari masyarakatnya, seperti; pengabaian, cercaan, hinaan, adalah paket yang selalu diterima Rasul dalam menjalankan dakwahnya. Namun, beliau tetap konsisten dan yakin bahwa suatu saat masyarakat akan berubah, dan benar doa dan perjuangan Rasul berbuah manis. Beliau mendapatkan pengikut; sahabat setia dalam menjalankan dakwahnya.

\section{Interpretasi Gaul Generasi Muda di Masyarakat}

Sikap gaul yang terjadi di masyarakat terkadang memberikan gambaran yang tidak baik. Ini menandakan bahwa gaul pada generasi muda perlu mendapatkan sentuhan dari berbagai pihak. Sebab, gaul yang cenderung kepada arah yang negatif akan memberikan dampak yang buruk pula bagi pelakunya. Karena sikap gaul yang dipilih keliru. Mohammad Anwar menyatakan hal tersebut sebagai perilaku menyimpang sebagai gambaran pola sikap dan tindakan individu atau kelompok yang tidak sesuai dengan norma atau nilai sosial yang berlaku di masyarakat akibat proses sosialisasi yang tidak sempurna (M. R. Lubis, 2017).

Namun, sebaliknya jika lihat dengan sadar, dalam menilai perilaku seseorang akan membawa manfaat buat kita. Seperti, semakin dewasa dalam memahami orang lain, kebijaksanaan akan lahir dari hati yang bersih dan pikiran yang sehat. Generasi muda akan mudah beradaptasi dengannya, karena tahu bagaimana kondisi latar belakangnya, dan paham cara untuk bergaul menempatkan diri sebagai teman yang peduli kepada teman lain. Sikap gaul seperti inilah yang diharapkan oleh setiap manusia. Tentu, generasi muda bisa melakukannya 
karena ada contohnya dari orang-orang terdahulu, secara khusus dari manusia mulia Nabi Muhammad SAW.

Seseorang yang diam bukan berarti ia tidak memilih sikap, justru diam itulah yang menjadi pilihannya dalam bergaul dengan yang lain. Dengan kata lain, sikap lebih diam dan sesekali berbicara yang dianggap perlu saja. Tentu ini merupakan bagian dari tipe-tipe psikologi kepribadian manusia. Kepribadian tidak bersifat statis, artinya kemungkinan besar selalu mengalami perubahan, tergantung bagaimana seseorang berinteraksi dengan orang lain (Daulay, 2014). Sebaliknya, seorang yang aktif, gemar berbicara juga merupakan pilihan sikap gaul dirinya. Ia lebih senang mengaktualisasikan potensi dan menjalankan hobinya dengan bebas. Sehingga ini perlu mendapatkan perhatian dari orang lain, agar hal tujuan baik dapat tercapai dengan cara yang baik pula.

Dengan demikian, gaya atau gestur tubuh syarat banyak makna, tidak bisa langsung menyimpulkan secara instan terhadap sikap seseorang. Sikap adalah kemampuan seseorang dalam menguasai emosinya dalam menyelesaikan pekerjaan dengan tutur kata dan perilaku yang baik (Taruh, 2020). Sebab, sikap gaul adalah bagian privasi seseorang dalam menentukan hal yang dianggap layak untuk dilakukannya. Dan kita sebagai teman atau orang yang menilai juga harus bersikap gaul secara benar, agar tidak ada terjadi salah gaul. Oleh karena itu, sikap yang dapat dilakukan adalah dengan tetap terus berbaur dan beradaptasi. Hindari sikap membedabedakan dalam pertemanan atas dasar fisik, karakter dan status sosial. Karena pada dasarnya setiap manusia memiliki sikap gaul yang bervariasi.

Berteman dengan banyak orang sungguh mengasyikkan, sebab mereka akan membantu di kala terjadi masalah. "Saling menolong" menjadi jargon bagi generasi muda yang memiliki ikatan pertemanan. Sebab mereka menyadari, di dunia ini tidak bisa hidup sendiri dan memenuhi kebutuhan tanpa bantuan orang lain. Juga generasi muda paham bahwa hidup sendiri cenderung individualis, yaitu sikap buruk akan muncul, seperti ego dan mudah merendahkan orang lain. Sehingga jika ada orang yang mementingkan diri sendiri sudah dapat dipastikan ia memiliki sedikit teman. Teman sedikit itu pun juga individu yang satu karakter dengan dirinya.

Zaman yang bergerak secara dinamis tersebut memberikan peringatan bahwa tidak boleh ada sikap apatis dan pasrah tanpa ada tindakan. Sikap pasif menunjukkan sesuatu yang tidak atau kurang baik. Putus asa adalah sikap apatis dan pasif yang menyebabkan seseorang enggan berusaha (Roqib, 2009). Dalam menghadapi kondisi yang ada harus bersikap lapang dada, menerima perbedaan dan perkembangan zaman. Jangan sampai kita menjadi manusia yang ditelan masa atau disebut korban zaman, namun sebaiknya generasi muda harus menjadi pengubah keadaan dan paham akan adaptasi dengan lingkungan. Generasi muda yang membawa perubahan dan pencerahan buat sesama, menjadi agen pengubah dan pencerah sebagai misi gaul masa muda.

Bergaul pada zaman sekarang hendaknya dipahami secara utuh oleh semua orang. Pemahaman secara utuh ini memberikan penekanan untuk memahami segala sesuatu dilihat dari banyak aspek. Seperti, perkembangan teknologi komunikasi seperti gawai, yang zaman sekarang hampir semua orang memiliki alat tersebut. Tidak sedikit generasi muda menghabiskan waktunya dengan gawai-nya, bermain game, sibuk berselancar di dunia maya dan banyak lagi. Seolah-oleh gawai menjadi teman hidup, yang kadang gawai seperti raja yang memperbudak manusia.

Zaman sekarang tidak bisa dianggap remeh atau dipandang sebelah mata, karena jika salah bergaul akan menempatkan diri sebagai perilaku negatif. Hal yang perlu dilakukan adalah 
bergaul secara luas, menjadi pribadi yang baik dan memiliki akhlak mulia. Sehingga disenangi teman-teman, dan juga Allah Swt. Generasi muda hendaknya berlatih membiasakan bergaul dengan benar dan terus belajar. Pengetahuan terus berkembang, setiap saat ditemukan pengetahuan baru. Oleh karena itu, belajar mengetahui harus terus dilakukan, bahkan ditingkatkan menjadi knowing much (berusaha tahu banyak) (Rusman, 2017). Itulah makna pergaulan yang luas, pergaulan yang membawa manfaat bagi orang di masyarakat.

Kumpulan orang-orang yang memiliki tipe individualis juga rentan terjadi gesekan pertengkaran. Mereka akan saling berlomba menunjukkan siapa diri yang paling hebat dan berpengaruh. Hebat dalam artian dari segi harta, kekuasaan, dan tindakan yang tanpa batas. Bisa jadi diantara mereka hanya mengambil manfaat atas popularitas seseorang. Ia diam dan dukung teman namun dari belakang sikap khianat dan pemanfaatan yang terjadi. Dengan demikian, pertemanan yang dibangun adalah pertemanan atas unsur pemanfaatan dan kepentingan. Jika seseorang sukses, maka teman-teman selalu ada di sisinya, namun jika terpuruk maka ia seorang diri meratapi kesepiannya.

Perumpamaan di atas sebagai contoh pergaulan keliru yang mengedepankan niat buruk dan merampas hak orang lain. Merampas hak ini dimaksudkan bukan hanya sekadar memanfaatkan harta dan kekuasaannya, lebih dari itu ia menanamkan strategi dan prinsip buruknya ke orang lain. Sehingga ia menguasai seluruh kehidupan seorang tanpa disadari sama sekali. Apa yang ia ucapkan maka itu yang menjadi keputusan itu yang diambil teman-nya. Teman tersebut seperti boneka yang dapat dimainkan sesuai kehendaknya. Kejadian itu bisa dihentikan jika ada muncul kesadaran dan cermat atas tindakan yang dilakukan bahwa ia telah terjebak dalam sikap gaul yang keliru.

Gaul seperti itu sangat merusak tatanan sosial, dan membawa keburukan buat dirinya dan orang lain. Sebagai generasi muda yang sadar dan peduli akan nasib orang lain tidaklah mungkin memilih cara gaul di atas. Sebab, banyak cara lain yang lebih baik dan halal dalam menempuh kesuksesan hidup, baik dunia dan juga akhirat. Dan yang terpenting dalam menjalani kehidupan ini adalah meraih berkah. Niat dan usaha yang dilakukan hendaknya berorientasi pada tindakan yang membawa berkah. Niat dan doa perlu dilakukan bersama agar setiap usaha dilakukan dengan sungguh-sungguh yang mengarah menuju terwujudnya sesuai keinginan (Rahmat, 2009). Karena keinginan meraih berkah akan memuaskan hati, memantapkan keimanan, juga memperbaiki hubungan pergaulan dengan teman.

Di sisi lain, mengidolakan publik figur tidak jadi masalah, selama yang profil idola sesuai dengan kriteria ajaran Islam. Seperti, ia mengajak masyarakat untuk beriman, melakukan perbuatan baik, dan menghormati orang tua, dan lainnya. Tentu mengidolakan seperti ini sangat dianjurkan, terlebih apa yang dinasihatkannya bisa pula kita amalkan. Dalam bahasan ini, sosok profil idola terbaik adalah Nabi Muhammad Saw. Karena, pada dirinya terdapat teladan tentang banyak aspek kehidupan. Keteladanan Rasul akan mampu membawa perubahan yang baik dalam hidup manusia, selanjutnya saat mampu menjalani teladannya maka itu bernilai ibadah di sisi Allah Swt.

Makna ala atau meniru tersebut menyarankan kepada kita untuk melihat substansi dan makna yang terkandung di dalamnya. Artinya, ada pesan yang bersifat umum atau terbuka dan ada pula pesan yang bersifat khusus atau tersirat. Dalam hal meniru juga sama, harus melihat substansi, seperti Rasul mengajarkan makan dengan 3 jari, tentu ini baik jika yang dimakan adalah buah kurma. Namun akan kesulitan jika makan mi instan dengan 3 jari. Artinya, perilaku 
Rasul makan dengan 3 jari, yang kadang kurang tepat digunakan pada semua kondisi. Tentu ini bukan berarti mengabaikan apa yang disunahkan Rasul.

Dari cuplikan contoh di atas perlu memperhatikan makna teks dan konteks. Makna teks adalah makna yang dapat ditarik pemahaman dengan mudah oleh semua orang. Seperti membaca koran, semua masyarakat akan dengan mudah membaca dan menyimpulkan isi dari suatu berita. Hal ini disebabkan tidak ada penafsiran lain atas teks atau redaksi dari bacaan tersebut. Informasi yang ditulis maka itulah yang menjadi poin pesan, perihal inilah yang disebut pesan umum dan terbuka.

Sedangkan, makna konteks adalah pemahaman yang lebih dari satu makna, sehingga perlu ada perujukan atau pertimbangan dari banyak pihak. Artinya, pesan konteks tidak semudah menarik kesimpulan pada pesan teks. Dengan demikian, pemaknaan teks dan konteks sejalan dengan yang ada teladannya dari Rasul. Pengaruh keteladanan berlaku untuk seluruh manusia dan tidak terikat dengan status sosial atau status intelektual, jika menurutnya baik ia akan menirunya walaupun tidak memahaminya (Taufik, 2020). Pemaknaan ini hanya bisa dipahami sebagian orang, lalu sebagian orang itu menyampaikan pada yang lain, sebab pesannya bersifat khusus atau tersirat. Generasi muda hendaknya cermat memahami sikap teladan dari teks dan konteks. Sikap yang paling aman adalah berpikir sejenak tentang suatu teks apakah itu relevan atau cocok dengan zaman sekarang, atau apakah bisa menarik kesimpulan dari teks tersebut. Dengan begitu kesesatan berpikir dapat dihindari.

Kesesatan berpikir adalah kesalahan dalam memahami makna suatu hal. Kesesatan berpikir ini disebabkan kesalahan dalam penggunaan bahasa sehari-hari, karena kebingungan mengenai isi bahasa yang digunakan (Efendi \& Susanti, 2020). Menyimpulkan tanpa memiliki kemampuan khusus atau pertimbangan mendalam atas hal yang terjadi. Kesesatan berpikir ini akan berlanjut kepada yang lain jika ia menyampaikannya kepada teman sejawat, jika sudah begini maka akan terjadilah sesat-menyesatkan. Oleh karena itu, generasi muda perlu mencermati dengan baik makna ganda atau pesan yang tersirat atas suatu masalah. Sehingga kita tidak akan terjebak dalam sikap gaul yang keliru, karena kesalahan fatal manusia adalah salah memilih jalan hidup. Dan sebaik-baik manusia yang bersalah ialah yang mau mengakui dan bertobat.

Dengan demikian, meniru secara teks dan konteks bukan hanya sekadar ikut-ikutan yang tanpa ilmu. Ikut-ikutan yang tanpa ilmu disebut dengan taklid buta. Taklid buta adalah mengikut saja apa saja yang dilakukan oleh panutan, tanpa berpikir, mencari informasi dan mungkin klarifikasi. Taklid buta dapat juga dipahami sebagai ketaklidan kepada seseorang yang membuat pelakunya kehilangan jati diri (Baharits, 1996). Taklid ini bisa terjadi karena manusia terlalu fanatik dengan idola yang ditirunya. Karena idola atau panutan tersebut memiliki pengaruh masa yang besar, atau seorang yang memiliki kekuasaan lebih, punya harta berlimpah, terkenal sebagai sosok pribadi dermawan, dimuliakan karena salehnya, dan banyak lagi.

Sikap menokohkan berlebihan terhadap yang ditiru bukanlah perkara yang baik. Kadang karena sikap mengidolakan terlalu berlebihan, pada saat dikecewakan oleh idolanya maka akan timbul stres, depresi, mengutuk dirinya dan idolanya dengan bahasa buruk. Tindakan tersebut malah akan memperburuk keadaan dirinya, ia akan kehilangan jati diri dan sosok panutan. Karena ia memulai meniru dengan niat yang keliru, cara yang salah, dan tindakan yang tanpa pertimbangan matang.

Tentu, sikap yang lebih bijak adalah meniru dengan berpikir, meniru atas dasar karena Allah dan cinta Nabi Muhammad Saw. Sehingga hal yang dilakukan tidak sia-sia, meniru dengan 
bijak selama baik maka boleh diikuti, namun jika ia buruk maka berikan koreksi walaupun ia orang terpandang, terhormat, dan dimuliakan. Selama mereka masih berstatus manusia, maka kecenderungan sikap salah dan khilaf masih dimungkinkan dapat terjadi karena itu bagian dari ciri sebagai manusia agar ia mendekatkan diri dan bertobat kepada Allah, dan berusaha belajar untuk tidak terjebak pada keburukan yang sama.

Dengan demikian, karena mengubah kebiasaan itu perlu proses karena sudah menjadi budaya kebiasaan, maka bagi generasi muda pada zaman sekarang ini harus membiasakan perbuatan baik sehingga menjadi budaya yang baik pula. Secara khusus, pembiasaan itu adalah pembiasaan yang berlandaskan pada risalah agama, selain membawa ketentraman juga bernilai ibadah. Pembiasaan akan membawa kepada pembentukan pribadi diri, apakah baik atau tidak baik (S. Lubis, 2018). Dengan kata lain, generasi muda hendaknya membudayakan agama namun jangan mengagamakan budaya. Artinya, pelan-pelan agama menjadi pijakan budaya sehari-hari.

Rasul mengajarkan kepada umatnya untuk beribadah dengan lurus dan tulus kepada Allah. Tidak mencampurkan keyakinan lain dalam ibadah kepada-Nya. Allah tidak menyukai persekutuan, karena siapa pun tidak dapat dan layak setara dengan-Nya. Rasul menyampaikan dengan penekanan yang serius dan disertakan dengan tata cara pelaksanaan risalah. Dengan tujuan, risalah tersebut dapat dilakukan umatnya sehingga bernilai ibadah di sisi Allah. Risalah yang baik haruslah diterapkan dengan cara yang baik pula, sebagai umat akhir zaman sudah sepatutnya mengamalkan risalah Rasul dan meneladaninya dengan sepenuh jiwa raga. Sampai akhirnya ajal menjemput, kita masih dapat menyebutkan nama Allah dan Rasul di sisa napas akhir, itulah yang harapkan semua umat Islam.

Rasul adalah manusia biasa. Bedanya dengan manusia pada umumnya adalah dari sisi tugasnya. Allah memberikan tugas dakwah kepada Rasul, yang bertujuan membawa risalah tauhid yang mengajak manusia kepada yang baik dan mencegah dari yang buruk. Dakwah itu selalu dipegang kuat oleh Rasul dalam hidupnya, sehingga para sahabat dan pengikutnya selalu bersamanya mendengarkan nasihat dan ajaran-ajaran syariat Islam. Ajaran Islam yang bersumber dari Alquran dan hadis adalah sikap beliau baik dari perkataan, perbuatan, maupun ketetapannya.

Tugas yang diberikan kepada Rasul adalah tugas mulia, karena di dalamnya terdapat sebuah makna yang hakiki yang berwaris secara runut dari Nabi awal yakni Nabi Adam hingga Nabi akhir, Muhammad Saw. Pesan makna tauhid tetap menjadi tujuan utama dalam misi risalah tersebut. Hambatan dan tantangan dalam dakwah menjadi bagian dari proses perjalanan seorang Rasul dalam mengembangkan dakwahnya. Karena pada saat itulah ia semakin yakin kebesaran Allah dan anugerah yang diberikan-Nya kepada semua Rasul.

Berusaha keras dalam berdakwah, dan menyerahkan hasilnya kepada Allah. Artinya, Rasul bertugas hanya sebagai pengingat, pemberi kabar gembira bagi umatnya. Tentang bahasan hidayah kepada manusia, perihal tersebut semua berpulang kepada izin dan kehendak Allah. Menurut ketetapan agama, ada dua hal besar yang merupakan tiang kebahagiaan dan pembimbing segala amal perbuatan manusia; 1)bahwa manusia memiliki usaha yang bebas dengan keinginan dan kehendaknya untuk mencari jalan yang bisa membawanya kepada kebahagiaan, dan 2)bahwa kodrat Allah tempat kembalinya segala makhluk (Abduh, 2016). Jadi, yang dilihat adalah proses yang dilaksanakan para khalifah di muka bumi. Dan Rasul menjalankan dakwah itu bukan sebagai beban dan keterpaksaan, namun sebagai wujud syukur dan rasa cinta kepada sang khalik. Menjalankan perintah Allah dengan rasa penghambaan 
totalitas. Inilah yang menjadi cahaya dakwah yang dijalankan oleh setiap Rasul yang hadir ke dunia.

Umat Islam, secara khusus generasi muda harus belajar dari sikap perjuangan yang diperankan oleh Rasul. Beberapa hal yang perlu dicermati dalam hal mengamalkan dakwah dalam kehidupan sehari-hari; Pertama, Mulai dari diri sendiri untuk berdakwah. Mendakwahi diri apakah perilaku diri selama ini sudah sesuai ajaran Islam. Melihat kembali secara cermat, baik dari sisi perkataan, pikiran, maupun perbuatan hendaknya sejalan dengan teladan Rasul.

Namun, jika belum berperilaku sesuai teladan Rasul, misi dakwah agar tetap untuk dilaksanakan. Jika umat Islam, khususnya generasi muda merasa dirinya hina, malu, takut salah sehingga tidak ada lagi yang mau berdakwah maka kepada siapa lagi tokoh penggerak dakwah dalam masyarakat. Ungkapan "saya belum mau berdakwah, saya takut tidak sesuai perbuatan dengan yang diucapkan." Ungkapan senada dengan ini, akan memberikan pengaruh berkurangnya tokoh dakwah di masyarakat. Maka yang harus menjadi jargon di masyarakat ialah walaupun saya belum mengamalkannya, saya berusaha untuk berdakwah, maka mulai detik ini saat apa yang saya ucapkan maka saya akan amalkan. Jika, generasi muda Islam punya prinsip seperti ini maka dakwah akan semakin mudah dan menguat di masyarakat.

Kedua, Saling mengingatkan. Mengingatkan penting untuk dilakukan karena kadang terjadi penurunan semangat dan motivasi dalam berdakwah, iman naik dan kadang juga turun. Generasi muda mengambil peran dengan memberi nasihat sabar dan mengingatkan kebaikan bagi yang lain agar selalu istiqomah di jalan Allah, mengamalkan ibadah dengan rapi dan khusuk. "Istiqomah dipahami sebagai suatu perbuatan dan perilaku tertentu yang terus menerus dilakukan seseorang dalam hidupnya secara tekun dan konsekuen (El-Hasany, 2020). Pada saat teman mendapat musibah maka sikap gaul adalah turut berempati dengan sekuat tenaga agar ia kembali kuat. Jika mendapatkan kesenangan atau rezeki dari Allah maka tidak lupa juga untuk membagi kebahagiaan kepada yang lain.

Dan Ketiga, Wujud cinta kepada Allah. Melakukan aktivitas atau kegiatan dakwah hendaknya tumbuh dari rasa cinta yang penuh kepada Allah. Rasa cinta tersebut akan membawa manusia untuk rida dan ikhlas atas semua takdir Allah yang mengikat pada setiap manusia. Bukan karena paksaan atau ingin mendapat kehormatan dari manusia, sebab alasan-alasan tersebut akan membawa kepada penyesalan dan keburukan. Perihal tersebut dapat membawa manusia menjadi kufur kepada Allah Pilihan ada di tangan manusia, sudah berapa besar cinta kepada Allah dan Rasul-Nya, jika masih tergolong kecil maka mulai sekarang tugas utama umat manusia, khususnya generasi muda ialah mencintai Allah dan Rasul.

Tentu, mencintai tersebut bukan hanya sekadar ucapan saja. Namun untuk membuktikan rasa cinta ialah dengan menjadikan Alquran dan Hadis sebagai pedoman hidup, maka isi pedoman itu harus diamalkan sekuat tenaga . Itulah yang mencirikan manusia yang cinta kepada Khaliknya, taat dan tunduk terhadap semua ketentuan-Nya. Sebaliknya, jika masih sebatas ucapan maka cinta itu belum tumbuh subur dengan baik, apalagi ucapan itu dipamerkan kepada masyarakat lain. Karena ucapan itu tergolong sia-sia, selain tidak diamalkan tetapi disebarluaskan, maka tentu perbuatan tersebut berseberangan dengan ajaran Islam, sehingga tindakan tersebut tergolong munafik.

\section{Kesimpulan}

Dengan demikian, dapat dipahami bersama bahwa Nabi Muhammad SAW adalah contoh suri teladan atau profil idola yang sangat tepat dijadikan rujukan oleh generasi muda 
membentuk akhlak mulia. Akhlak mulia yang bersikap dan bergaul ala Rasul, berusaha sekuat tenaga meniru jejak langkahnya, memikirkan nasihat dan ucapan kebijaksanaannya, mencintai dan mendoakannya sebagai wujud taat kepada Allah Swt. Gaul ala Rasul inilah yang perlu diimplementasikan oleh seluruh masyarakat, secara khusus generasi muda Islam. Mempraktikkan kebaikan sehingga menjadi agen perubahan dan pencerahan bagi umat manusia.

Percepatan informasi dan teknologi serta pergerakan budaya yang silih berganti menjadi tantangan berat bagi masyarakat. Dengan makna lain, jika generasi muda tidak membekali diri dengan pemikiran yang baik, keimanan dan akhlak mulia dikhawatirkan terbawa budaya atau lingkungan yang mengajaknya pada keburukan. Upaya antisipasi dari pengaruh buruk kurang berjalan dengan baik, sebab alat filter pada manusia; akal, hati, dan agama tidak difungsikan. Alat filter itu dikenal dengan nama iman dan ilmu, sebagai tonggak kuat agar manusia tetap istiqomah menjalankan ibadah dan taat kepada Allah. Tidak sedikit generasi muda tenggelam dalam lingkungan buruk dikarenakan tidak bersikap dan bergaul ala Rasul.

Gaul ala Rasul hendaknya menjadi semangat dan motivasi hijrah bagi masyarakat Muslim yang ingin pribadinya menjadi baik. Bergaul dengan sikap teladan dari Rasul, dari sisi perkataan dan perbuatannya. Karena sudah saatnya masyarakat Muslim kembali sungguh-sungguh mengamalkan nasihat Rasul dalam kehidupan sehari-hari. Mengingat kondisi peradaban budaya pada masyarakat perlu mendapatkan pencerahan secara berkelanjutan.

Akhirnya, dalam rangka melanjutkan dakwah Rasul di dunia ini maka harus ada sebagian masyarakat atau generasi muda yang turut andil menyebarkan dakwah Islam. Selanjutnya, setiap orang Muslim hendaknya memiliki perilaku dan bergaul seperti teladan Rasul. Bukan meniru atau mencontoh simbol-simbol saja, namun yang paling penting adalah mencontoh perilaku bermasyarakat, perilaku menjadi pemimpin yang adil, kepala rumah tangga yang baik, pebisnis yang sukses, pendakwah yang sabar, pribadi yang sederhana, dan generasi muda yang tangguh. Artinya, mencontoh perihal yang lebih substansi; pengamalan ibadah kepada Allah dan berhubungan baik dengan sesama manusia dan alam lingkungan sekitar.

\section{DAFTAR PUSTAKA}

Abduh, S. M. (2016). Risalah Tauhid. Jakarta: Titah Surga.

Ananta, U. Y. (2018). Merajut Mimpi Pemuda Hari Esok. Yogyakarta: Diandra Kreatif.

Az-Za'balawi, M. S. M. (2007). Pendidikan Remaja antara Islam \& Ilmu Jiwa. Jakarta: Gema Insani Press.

Baharits, A. H. S. (1996). Tanggung Jawab Ayah Terhadap Anak Laki-Laki. Jakarta: Gema Insani. Daulay, N. (2014). Pengantar Psikologi dan Pandangan Al-Qur'an Tentang Psikologi. Jakarta: Kencana.

Efendi, A., \& Susanti, D. O. (2020). Logika \& Argumentasi Hukum. Jakarta: Kencana.

El-Hasany, I. S. (2020). Keajaiban Istiqomah. Bekasi: Al-Muqsith Pustaka.

Lubis, M. R. (2017). Sosiologi Agama: Memahami Perkembangan Agama dalam Interaksi Islam. Jakarta: Kencana.

Lubis, S. (2018). Menguatkan Karakter Melalui Pembiasaan. Aceh: Yayasan Cahaya Bintang Kecil.

Mardiyansyah, D., \& Senda, I. (2011). Keajaiban Berperilaku Positif. Jakarta: Tangga Pustaka.

Rahmat. (2009). Meraih Berkah Dan Pahala Melalui Internet. Jakarta: PT. Elex Media 
Komputindo.

Rochmi, M. N. (2012). Surat dari \& untuk pemimpin: menjadi Indonesia (p. 154). Jakarta: Tempo Publishing.

Roqib, M. (2009). Ilmu Pendidikan Islam; Pengembangan Pendidikan Integratif di Sekolah. Yogyakarta: LKiS.

Rusman. (2017). Belajar \& Pembelajaran: Berorientasi Standar Proses Pendidikan. Jakarta: Kencana.

Saputra, R. A. (2018). Menyesali Masa Lalu, Memperjuangkan Masa Depan - Robi Afrizan Saputra. Jakarta: Kompas Gramedia.

Sunaryo. (2004). Psikologi Untuk Keperawatan. Jakarta: Buku Kedokteran EGC.

Taruh, F. (2020). Motivasi Kerja (Meniti Suara Hati Menolak Perilaku Korupsi). Yogyakarta: Deepublish.

Taufik, T. (2020). Dakwah Era Digital: Sejarah, Moetode dan Perkembangan. Kuningan: Pustaka Al-Ikhlas. 
